\title{
Non-destructive in situ identification of the moisture content in saline brick walls using artificial neural networks
}

\author{
Anna Hoła ${ }^{a}$, Łukasz Sadowski* ${ }^{\text {a* }}$ \\ ${ }^{a}$ Wroclaw University of Science and Technology, Faculty of Civil Engineering, Wybrzeze Wyspianskiego 27, 50-370 Wroclaw, Poland
}

\begin{abstract}
The article proposes a method of neuron identification of the moisture content in saline brick walls of historic buildings, carried out on the basis of non-destructive testing. The method is based on the use of artificial neural networks, which were trained, tested and experimentally verified on a set of data constructed for this purpose. The set consists of test results that were obtained using non-destructive methods on a selected representative group of historic masonry buildings. Based on numerical analyzes, an appropriate type and structure of the ANN and learning algorithm were selected. Positive results were obtained, which indicated the possibility of using the proposed method in practice.
\end{abstract}

(C) 2019 The Authors. Published by Budapest University of Technology and Economics \& Diamond Congress Ltd.

Peer-review under responsibility of the scientific committee of the Creative Construction Conference 2019.

Keywords: budynki zabytkowe, mury ceglane, wilgotność, badania nieniszczace, sztuczne sieci neuronowe

\section{Introduction}

Maintaining the appropriate condition of historic buildings, which are testimonies of past epochs, is of significant social interest due to their artistic and historical value. In order to keep these building objects in good condition, various technical problems must be faced, including one of the most common - the excessive moisture of walls. This moisture is caused by the lack of damp-proof insulation that was not previously executed [1-3]. Long-lasting direct contact of a wall with the ground causes water molecules that are contained in the ground, along with the salts dissolved in them, to gradually penetrate into the components of the wall, while at the same time dampening and salting them. This contributes to moisture destruction [4-5] that progresses over time, the exemplary effects of which are shown in Figure 1. The negative effects of excessive moisture are compounded by the destructive effects of water-soluble salts. As a result of the crystallization and hydration processes that take place in the sub-surface zone of a wall - in the capillaries and pores - and on its surface, salts break up the masonry structure and form surface salt efflorescence [5-7].

Before conducting conservation actions that lead to the stopping of the above-mentioned destructive processes, and consequently the preserving of historic tissue in an appropriate condition, it is necessary to carry out tests that aim to determine the size and causes of the moisture content and salinity.

In literature [8-12], it has often been signaled that among all the known methods of testing the moisture content in brick walls, the most reliable results are obtained by the gravimetric method. This allows the moisture content values to be determined on the surface, as well as along the thickness of the tested partition. During its use, however, it is 
Anna Hoła, et al. / Proceedings of the Creative Construction Conference (2019) 012 https://doi.org/10.3311/CCC2019-012

necessary to take in situ samples of material for laboratory tests, which in the case of historic building objects is usually only possible to a very limited extent. In the case of evaluating salinity, the possibilities are greater because interference with the wall is minimal. This is due to the fact that only small samples of a few grams are taken for testing from the subsurface zone where the salt content is the largest. Due to this limitation, non-destructive methods are predisposed to perform tests of the moisture content in brick walls of historic buildings. However, they also have some limitations in their usage and require so-called scaling, which is discussed later in the article. The ignorance of their specificity may lead to unreliable results being obtained.
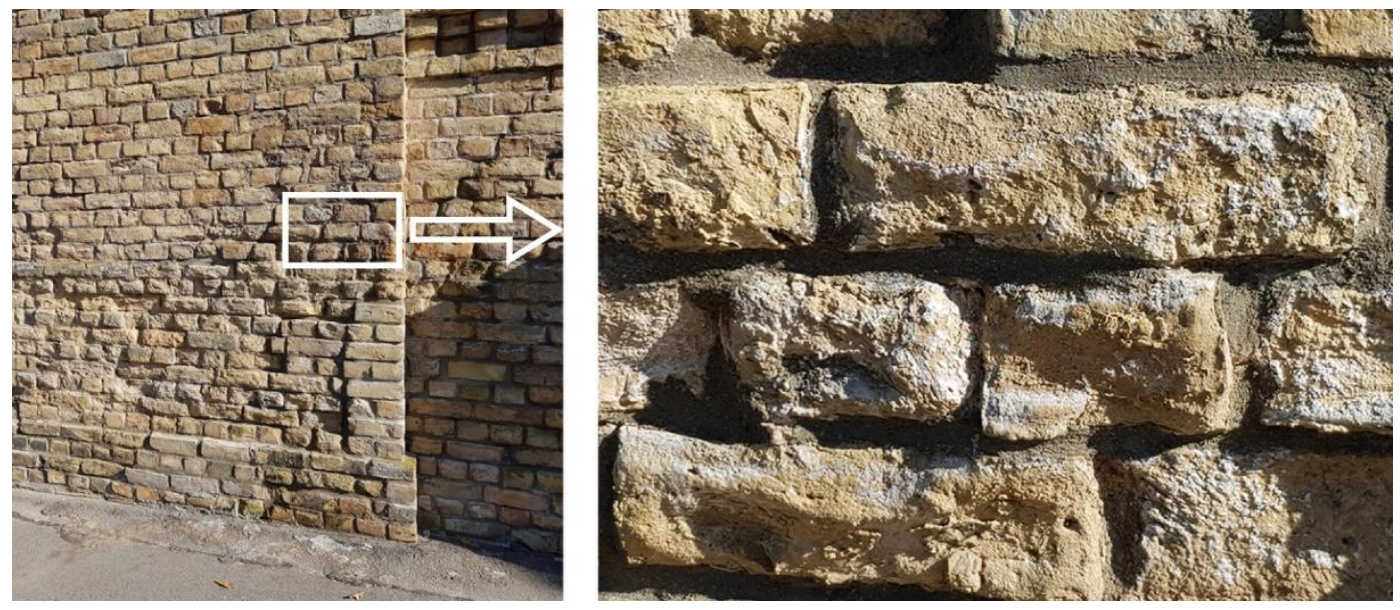

Fig. 1. Moisture destruction of a brick wall in a historic building

Bearing in mind the above, the aim of the article is to propose a neural non-destructive method for assessing the moisture content in the saline brick walls of historic buildings. It eliminates, to the maximum extent, the necessity of interfering with the historical tissue of a building object, which is unavoidable in the case of testing the moisture content using the gravimetric method. It also eliminates the need to scale apparatus each time it is used for nondestructive testing, which is necessary for the correct interpretation of results.

The proposed method of assessment is based on the use of artificial neural networks, which are trained, tested and experimentally verified on a data set that was constructed for this purpose. This set consists of the results of tests that were obtained on a representative group of historic brick buildings erected in different historical periods. It is assumed that the network that is trained on this set, after the experimental verification carried out on other historic buildings, will be useful for the correct identification of the moisture content of saline walls. This identification will be conducted with minimal interference in the wall structure, and be based on the carried out non-destructive tests. The data set contains two parameters that are determined using non-destructive methods - dielectric and microwave - and three parameters that describe the concentration of basic salts found in the damp walls, which are indicated using the semiquantitative method. The usefulness of this approach regarding in situ objects was confirmed on the basis of tests carried out in laboratory conditions [13]. This publication presents the effects of work in the form of a constructed data set that consists of the above-mentioned parameters, as well as the results of training, testing and experimental verification of the selected artificial neural network.

\section{Methodology of testing}

In order to build a set of data for the purpose of training, testing and experimentally verifying artificial neural networks, in-situ investigations of the moisture content in brick walls were carried out in a few selected historic buildings. These buildings were erected in different years and historical periods and were made of full ceramic brick and lime mortar. The mentioned representativeness is manifested in the fact that the obtained results of the tests of the moisture content and wall salinity are within wide ranges. In each of the building objects, measuring points were selected in various, 
Anna Hoła, et al. / Proceedings of the Creative Construction Conference (2019) 012 https://doi.org/10.3311/CCC2019-012

but similar to each other, amounts, which was required by the conservation services. The list of building objects is shown in Table 1.

More than 200 sets of results were included in the data set. Each set consists of six parameters: two dimensionless that describe the moisture content of a wall, and three that describe the molar concentration of the three basic salts that can be found in the tested brick walls (nitrates, chlorides, sulphates). The above-mentioned parameters were obtained from tests that used two non-destructive electric methods: the dielectric method with the use of the GANN UNI 2 dielectric meter with a ball probe, and the microwave method with the use of the T600 microwave meter. From each of the measuring points, a specimen was collected for gravimetric tests in order to determine the salt concentration using the semi-quantitative method, and also to determine the real mass moisture content $U_{\mathrm{m}}$, which is the sixth parameter that is necessary to train an ANN.

Table 1. Basic information about the buildings in which tests were conducted in order to build a data set

\begin{tabular}{|c|c|c|}
\hline No. & & Building description \\
\hline \multirow{4}{*}{1.} & Name, location & monastery of the Benedictine Abbey, Pomerania, Poland \\
\hline & Construction date & the turn of the thirteenth and fourteenth centuries \\
\hline & $\begin{array}{l}\text { Description of the building } \\
\text { object }\end{array}$ & $\begin{array}{l}\text { erected according to the classical scheme of the Cistercian monastery that is based on a quadrangle } \\
\text { of buildings gathered around a patio surrounded by cloisters }\end{array}$ \\
\hline & $\begin{array}{l}\text { Place of conducting } \\
\text { measurements }\end{array}$ & $\begin{array}{l}\text { - basement rooms under the northern wing of the monastery } \\
\text { - wall thickness ranging from } \sim 60 \mathrm{~cm} \text { to } \sim 180 \mathrm{~cm}\end{array}$ \\
\hline \multirow{4}{*}{2.} & Name, location & pavilion at Wzgorze Partyzantow, Wroclaw, Poland \\
\hline & Construction date & XVI - XIX century \\
\hline & $\begin{array}{l}\text { Description of the building } \\
\text { object }\end{array}$ & $\begin{array}{l}\text { - erected in the place of the former bastion } \\
\text { - located at the foot of a hill; some of its external walls are partially covered with soil } \\
\text { - a single-storey building kept in a style that refers to the Italian Renaissance }\end{array}$ \\
\hline & $\begin{array}{l}\text { Place of conducting } \\
\text { measurements }\end{array}$ & $\begin{array}{l}\text { - internal and external walls that are in contact with the ground, and also the ones that are not in } \\
\text { contact with the ground } \\
\text { wall thickness of about } \sim 85 \mathrm{~cm}\end{array}$ \\
\hline \multirow{4}{*}{3.} & Name, location & building of the Heimann Foundation, Wroclaw, Poland \\
\hline & Construction date & XIX wiek \\
\hline & $\begin{array}{l}\text { Description of the building } \\
\text { object }\end{array}$ & $\begin{array}{l}\text { - erected by the foundation of Wroclaw bankers E. and H. Heimann as a nursing home for the poor } \\
\text { inhabitants of Wrockaw } \\
\text { - a three-storey building in a style that refers to the Middle Ages }\end{array}$ \\
\hline & $\begin{array}{l}\text { Place of conducting } \\
\text { measurements }\end{array}$ & $\begin{array}{l}\text { - external walls of basement rooms } \\
\text { - wall thickness of about } \sim 60 \mathrm{~cm} \text { to } \sim 80 \mathrm{~cm}\end{array}$ \\
\hline \multirow{4}{*}{4.} & Name, location & $\begin{array}{l}\text { residential building, } \\
\text { Nowa Ruda, Poland }\end{array}$ \\
\hline & Construction date & XIX century \\
\hline & $\begin{array}{l}\text { Description of the building } \\
\text { object }\end{array}$ & - the building has a basement under a part of it and three above-ground storeys \\
\hline & $\begin{array}{l}\text { Place of conducting } \\
\text { measurements }\end{array}$ & $\begin{array}{l}\text { - external and internal walls of the basement rooms and ground floor } \\
\text { - wall thickness of about } \sim 50 \mathrm{~cm}\end{array}$ \\
\hline \multirow{4}{*}{5.} & Name, location & administrative building, Wroclaw, Poland \\
\hline & Construction date & the end of the 19th century \\
\hline & $\begin{array}{l}\text { Description of the building } \\
\text { object }\end{array}$ & $\begin{array}{l}\text { - the building has a basement and four above-ground storeys } \\
\text { wall thickness of about } \sim 80 \mathrm{~cm}\end{array}$ \\
\hline & $\begin{array}{l}\text { Place of conducting } \\
\text { measurements }\end{array}$ & - external walls of the basement rooms \\
\hline
\end{tabular}

\section{Test results}

Table 2 contains part of the data set consisting of a total of 205 sets of results. Each set has two dimensionless parameters - $X_{D}$ and $X_{M}$ - which were determined non-destructively using the dielectric and microwave methods, respectively; three parameters $X_{A}, X_{C}$, and $X_{S}$ that describe the molar concentrations (in \%) of nitrate, chloride and 
Anna Hoła, et al. / Proceedings of the Creative Construction Conference (2019) 012

https://doi.org/10.3311/CCC2019-012

sulphate salts, which were determined using the semi-quantitative method; and also parameter $U_{m}$ that describes the real mass moisture content of the wall (in \%), which was obtained using the gravimetric method. From the obtained data set, 145 randomly selected sets of results were designated for training, 31 were randomly selected for testing, and 29 were randomly selected for experimental verification of the artificial neural network.

Table 2. Data set

\begin{tabular}{|c|c|c|c|c|c|c|}
\hline $\begin{array}{c}\text { Data set } \\
\text { number } \\
{[-]}\end{array}$ & $\begin{array}{c}\text { Parameter } \\
\text { describing the } \\
\text { moisture } \\
\text { content, which } \\
\text { was determined } \\
\text { using the } \\
\text { dielectric } \\
\text { method } \\
X_{D}[-]\end{array}$ & $\begin{array}{c}\text { Parameter } \\
\text { describing the } \\
\text { moisture } \\
\text { content, which } \\
\text { was determined } \\
\text { using the } \\
\text { microwave } \\
\text { method } \\
X_{M}[-]\end{array}$ & $\begin{array}{c}\text { Parameter } \\
\text { describing the } \\
\text { molar } \\
\text { concentration of } \\
\text { nitrate salts } \\
\text { in the wall } \\
X_{A}[\%]\end{array}$ & $\begin{array}{c}\text { Parameter } \\
\text { describing the } \\
\text { molar } \\
\text { concentration of } \\
\text { chloride salts } \\
\text { in the wall } \\
X_{C}[\%]\end{array}$ & $\begin{array}{c}\text { Parameter } \\
\text { describing the } \\
\text { molar } \\
\text { concentration of } \\
\text { sulphate salts } \\
\text { in the wall } \\
X_{S}[\%]\end{array}$ & $\begin{array}{l}\text { Parameter } \\
\text { describing the } \\
\text { real mass } \\
\text { moisture } \\
\text { content of the } \\
\text { wall } \\
U_{\mathrm{m}}[\%]\end{array}$ \\
\hline 1 & 133,8 & 74,0 & 0,033 & 0,250 & 0,000 & 8,45 \\
\hline 2 & 74,5 & 33,2 & 0,035 & 0,300 & 0,000 & 1,84 \\
\hline 3 & 121,6 & 34,5 & 0,055 & 0,300 & 0,010 & 6,25 \\
\hline 4 & 131,7 & 43,2 & 0,060 & 0,350 & 0,100 & 4,48 \\
\hline 5 & 104,4 & 33,3 & 0,045 & 0,300 & 0,025 & 1,52 \\
\hline 6 & 141,9 & 24,5 & 0,048 & 0,200 & 0,010 & 5,77 \\
\hline 7 & 120,7 & 25,5 & 0,047 & 0,250 & 0,000 & 2,65 \\
\hline 8 & 63,0 & 26,4 & 0,040 & 0,200 & 0,000 & 1,39 \\
\hline 9 & 129,5 & 34,6 & 0,025 & 0,250 & 0,000 & 4,07 \\
\hline 10 & 93,3 & 30,3 & 0,022 & 0,250 & 0,000 & 2,17 \\
\hline 11 & 64,7 & 29,6 & 0,037 & 0,300 & 0,010 & 3,67 \\
\hline 12 & 95,8 & 33,4 & 0,022 & 0,200 & 0,000 & 4,06 \\
\hline 13 & 97,6 & 27,5 & 0,020 & 0,200 & 0,000 & 3,61 \\
\hline 14 & 88,6 & 30,0 & 0,032 & 0,250 & 0,000 & 2,75 \\
\hline 15 & 81,0 & 29,8 & 0,030 & 0,250 & 0,000 & 4,11 \\
\hline 16 & 120,5 & 35,5 & 0,029 & 0,250 & 0,000 & 8,69 \\
\hline 17 & 48,5 & 22,0 & 0,040 & 0,250 & 0,000 & 1,65 \\
\hline 18 & 140,8 & 41,4 & 0,098 & 0,300 & 0,025 & 5,48 \\
\hline 19 & 105,2 & 33,5 & 0,018 & 0,200 & 0,000 & 3,39 \\
\hline 20 & 62,0 & 30,7 & 0,040 & 0,200 & 0,000 & 2,51 \\
\hline 21 & 75,3 & 27,0 & 0,056 & 0,200 & 0,000 & 3,94 \\
\hline 22 & 47,9 & 24,1 & 0,020 & 0,200 & 0,000 & 0,98 \\
\hline 23 & 77,9 & 31,6 & 0,034 & 0,200 & 0,000 & 3,80 \\
\hline 24 & 46,6 & 29,0 & 0,049 & 0,250 & 0,000 & 1,74 \\
\hline 25 & 55,0 & 30,9 & 0,035 & 0,300 & 0,000 & 1,56 \\
\hline 26 & 78,3 & 33,2 & 0,039 & 0,250 & 0,025 & 1,88 \\
\hline 27 & 41,3 & 28,5 & 0,030 & 0,200 & 0,000 & 1,29 \\
\hline 28 & 103,6 & 31,8 & 0,032 & 0,200 & 0,000 & 1,60 \\
\hline 29 & 76,7 & 37,2 & 0,070 & 0,350 & 0,025 & 1,82 \\
\hline 30 & 70,8 & 30,4 & 0,030 & 0,250 & 0,010 & 1,22 \\
\hline 205 & 121,6 & 34,5 & $0,055^{\cdot}$ & 0,300 & 0,010 & 6,25 \\
\hline
\end{tabular}

\section{Numerical analysis}

A unidirectional multilayer artificial neural network with back-propagation error, the conjugate gradient (CG) algorithm, and the number of hidden layer neurons equal to 3 was selected for the purpose of training and testing in order to non-destructively identify the value of the moisture content $U_{m c}$. Figure 2 shows the relationship between the real moisture content $U_{m}$ that was obtained using the gravimetric method, and the moisture content $U_{m c}$ that was identified by the unidirectional multilayer artificial neural network with back-propagation error, the conjugate gradient 
Anna Hoła, et al. / Proceedings of the Creative Construction Conference (2019) 012 https://doi.org/10.3311/CCC2019-012

(CG) algorithm, the number of hidden layer neurons equal to 3 , and the number of epochs equal to 150 . Figure $2 \mathrm{a}$ shows this dependence for the training process, while Figure $2 \mathrm{~b}$ shows it for the testing process. From Figure 2a it can be concluded that the network correctly maps the training data and correctly identifies the testing data. This is evidenced by the location of points along the regression line that corresponds to the ideal mapping and the high values of the linear correlation coefficient $\mathrm{R}$ that are equal to 0.919 and 0.928 for the training process and testing process, respectively.
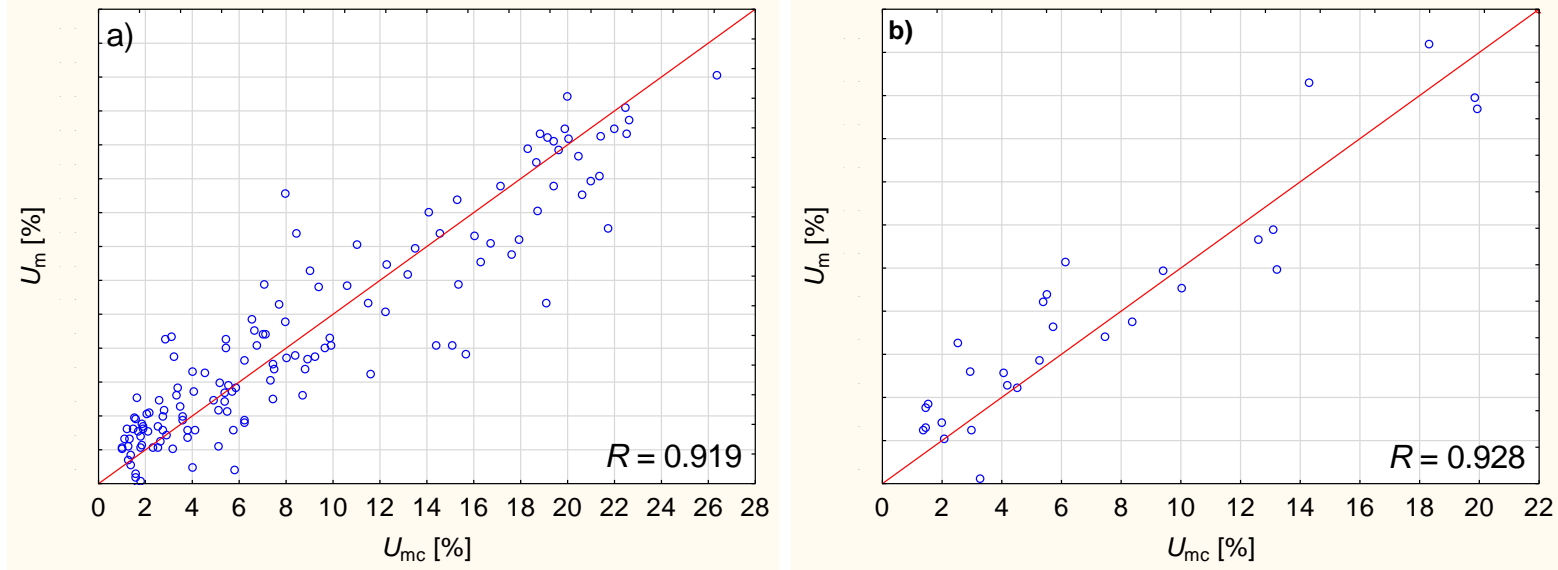

Fig. 2. Relationship between the mass moisture content Um of the tested walls that was obtained using the gravimetric method, and the moisture content $U_{m c}$ that was identified by the network for the process of: a) training; b) testing

In turn, Figure 3 shows the relationship between the moisture content $U_{\mathrm{m}}$ that was obtained on the basis of experimental tests, and the moisture content $U_{m c}$ that was identified by the network for the process of experimental verification. The obtained results show that the network correctly maps randomly selected verification data. This is confirmed by the location of points along the regression line, which corresponds to the ideal mapping, as well as by the obtained high value of the linear correlation coefficient $\mathrm{R}$, which is equal to 0.906 .

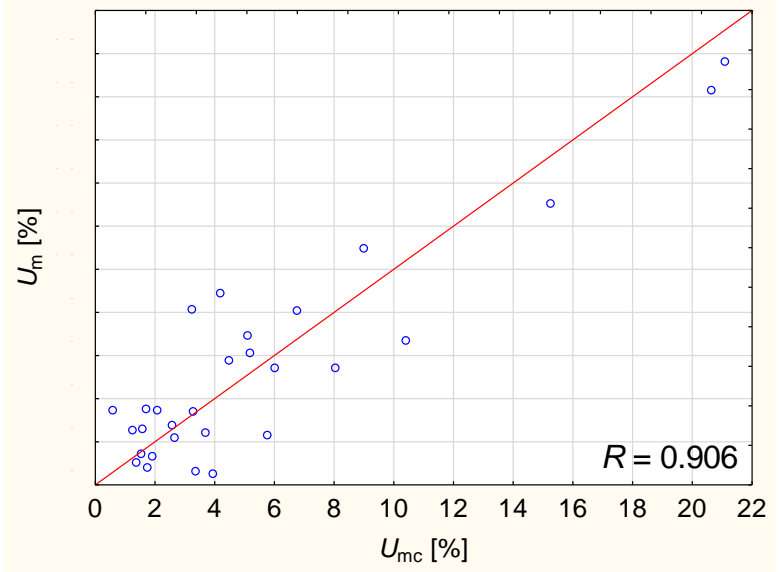

Fig. 3. The relationship between the mass moisture content $U_{\mathrm{m}}$ that was obtained on the basis of experimental tests, and the moisture content $U_{m}$ that was identified by the ANN for experimental verification 
Anna Hoła, et al. / Proceedings of the Creative Construction Conference (2019) 012 https://doi.org/10.3311/CCC2019-012

\section{Summary}

On the basis of the conducted moisture content tests of saline brick walls in five historic buildings, a data set consisting of more than two hundred sets of results was built. Each set has six parameters: two that describe the moisture content assessed using non-destructive dielectric and microwave methods, three that describe the salinity assessed using the semi-quantitative method, and also the mass moisture content evaluated using the gravimetric method. This set was used for training, testing and experimental verification of a selected unidirectional multilayer artificial neural network with back-propagation error, which was chosen for the purpose of identifying the moisture content of brick walls in buildings that are historically valuable.

The carried out numerical analyses proved that it is possible to reliably identify the moisture content of saline brick walls using artificial neural networks that have an appropriately selected structure and learning algorithm based on the parameters from which the data set was created. A unidirectional multilayer artificial neural network with backpropagation error and the conjugate gradient algorithm is predisposed for this purpose. This is evidenced by the obtained high values of the linear correlation coefficient $\mathrm{R}$ of $0.919,0.928$ and 0.906 for the training, testing and experimental verification processes, respectively.

The proposed neuronal method of assessing the moisture content based on parameters evaluated using non-destructive methods, despite the obtained positive result of experimental verification in numerical analyses of the above-mentioned artificial neural network, still requires verification on other historic buildings. These works are currently being carried out. After their completion, it will be possible to more often use the described method in construction practice.

\section{References}

[1] A. Hoła, „Tests of the damp timber-framed construction of a historic church building,” International Review of Civil Engineering, tom 6, nr 2, pp. 39-42, 2015. https://doi.org/10.15866/irece.v6i2.6322

[2] F. Frössel, Osuszanie murów i renowacja piwnic, Warszawa: Wydawnictwo Polcen, 2007.

[3] A. Hoła, „Non-destructive testing of the damp walls of the basements in a gothic monastery,” w 12th European Conference on Nondestructive Testing [Dokument elektroniczny] , Gothenburg, 2018.

[4] M. S. Camino, F. J. León, A. Llorente i J. M. Olivar, „Evaluation of the behavior of brick tile masonry and mortar due to capillary rise of moisture," Materiales de Construcción, tom 64, nr 314, p. e020, 2014. http://dx.doi.org/10.3989/mc.2014.02513

[5] C. Gentilini, E. Franzoni, S. Bandini i L. Nobile, ,Effect of salt crystallisation on the shear behaviour of masonry walls: an experimental study," Construction and Building Materials, nr 37, pp. 181-189, 2012. https://doi.org/10.1016/j.conbuildmat.2012.07.086

[6] F. Wołoch, M. Gaczek i S. Fiszer, „The influence of salts on building elements,” Builder, No. 12, pp. 70-74, 2017.

[7] R. L. Espinosa, L. Franke i G. Deckelmann, „Phase changes of salts in porous materials. Crystallization, hydration and deliquescence,” Construction and Building Materials, nr 22, pp. 1758-1773, 2008. https://doi.org/10.1016/j.conbuildmat.2007.05.005

[9] M. Rokiel, Hydroinsulations in the building industry, Warsaw: Grupa MEDIUM, 2006.

[10] A. Hoła, „Measuring of the moisture content in brick walls of historical buildings - the overview of methods,” w 3rd International Conference on Innovative Materials, Structures and Technologies (IMST 2017) [Dokument elektroniczny], IOP Publishing: Materials Science and Engineering, Riga, Latvia, 2017. https://doi.org/10.1088/1757-899X/251/1/012067

[11] D. Watt i B. Colston, „Investigating the effects of humidity and salt crystallisation on medieval masonry,” Building and Environment, tom 35, nr 8, pp. 737-749, 2000. http://dx.doi.org/10.1016/S0360-1323(00)00015-9

[12] F. Sandrolini i E. Franzoni, „An operative protocol for reliable measurements of moisture in porous materials of ancient buildings,” Building and Environment, tom 41, nr 10, pp. 1372-1380, 2006. https://doi.org/10.1016/j.buildenv.2005.05.023

[13] A. Goetzke-Pala, Ł. Sadowski i A. Hoła, „A non-destructive method of the evaluation of the moisture in saline brick walls using artificial neural networks," Archives of Civil and Mechanical Engineering, tom 18, nr 4, pp. 1729-1742, 2018.

https://doi.org/10.1016/j.acme.2018.07.004 